\title{
The Monetary Base and Bank Lending: You Can Lead a Horse to Water...
}

\author{
David C. Wheelock, Vice President and Banking and Financial Markets Adviser
}

I $\mathrm{n}$ its response to the worsening financial crisis during the fall of 2008, the Federal Reserve took actions that dramatically increased the size of the monetary base (the sum of currency in circulation and depository institution deposits with the Fed) (see chart). Subsequently, the Fed purchased some $\$ 1.7$ trillion of securities issued by the U.S. Treasury and federally sponsored housing agencies, which expanded the monetary base further. The base more than doubled in size between September 2008 and May 2010. Yet measures of the money stock, such as MZM, M1, and M2, increased far less. For example, M1 increased about 17 percent over these months; consequently, the ratio of M1 to the monetary base (measured by the St. Louis Adjusted Monetary Base), commonly referred to as the "M1 money multiplier," fell from about 1.6 to 0.84 .

Why was the increase in the money stock so small when the increase in the monetary base was so large? The answer centers on the willingness of depository institutions (banks) to lend and the perceived creditworthiness of potential borrowers. A deposit is created when a bank makes a loan. Ordinarily, bank loans-and hence deposits-increase when the Fed adds reserves to the banking system. However, despite an increase in reserves of over \$1 trillion, total commercial bank loans were some $\$ 200$ billion lower in May 2010 than in September 2008. Banks added to their holdings of securities, which resulted in a modest increase in deposits and the money stock, but many banks were reluctant to make new loans. Partly this reflected weak loan demand, but it also indicated a diminished appetite for risk on the part of bankers. Further, a lack of equity capital (and a high cost of obtaining additional capital) constrained the lending of many banks (banks are subject to minimum capital requirements based on their outstanding loans and other assets).

\section{Why was the increase in the money stock so small when the increase in the monetary base was so large?}

Many economists worry that bank lending and monetary growth will eventually surge and, ultimately, cause higher inflation. Minutes of Federal Open Market Committee meetings indicate that Fed officials have discussed possible measures to discourage excessive growth in lending and the money stock. One option is to sell securities outright or under repurchase agreements, which would shrink the monetary base. Recent experience illustrates, however, that large changes in the base may be necessary to effect the

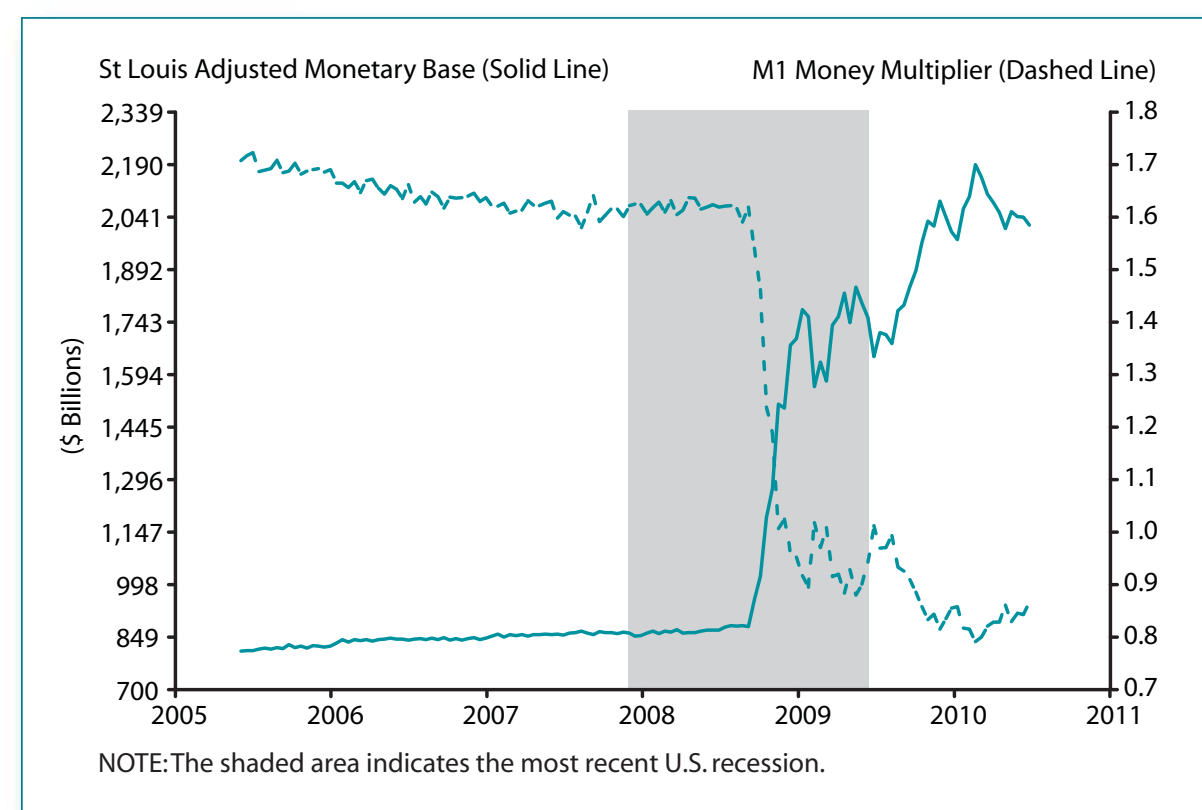


desired changes in bank lending. Another option is to raise the interest rate paid to banks on their reserve deposits, which would raise the opportunity cost of lending and thereby tend to exert upward pressure on market rates generally and slow the growth of loans and the money stock. However, because the Fed has little experience with paying interest on reserves, it is difficult to predict how much bank loans would change in response to an increase in the interest rate paid on reserve deposits. ${ }^{1}$ Hence, the Fed may resort to both options if monetary growth threatens to become excessive.
${ }^{1}$ The Federal Reserve has paid interest on bank reserve deposits since October 2008 under authority granted by the Emergency Stabilization Act of 2008 (see Richard G. Anderson, "Paying Interest on Deposits at Federal Reserve Banks," Federal Reserve Bank of St. Louis Economic Synopses, No. 30, 2008; http://research.stlouisfed.org/publications/es/08/ES0830.pdf). 